\title{
The Rise of Islamic Values in Media: A Three Dimensions Analysis of Film Industry in Indonesia
}

\author{
Muhamad Fadhil Nurdin \\ Universitas Padjajaran, Jawa Barat, Indonesia \\ Fitaha Aini \\ Universitas Islam 45, Jawa Barat, Indonesia \\ Vina Effendi, Mohamad Saleeh Bin Rahamad \\ University of Malaya, Kuala Lumpur, Malaysia
}

\begin{abstract}
This article focuses on the rise of Islamic values in media with concern to the film industry in Indonesia. In this nation, $88.22 \%$ of 254 million of the population are Muslims. However, this substantial quantity is burden some if Muslims have a lack of appreciation to history and are intellectually weak. In addition, cultural degradation due to the rapid changes in information \& communication technology diminishes moral and ethics of society. The growth of film industry in the Soeharto era which curb freedom of expression and media resulted in films which were more oriented to comedy, horror, and vulgar. The aims of this study specifically are: (1) to identify the film industry (macro) in the context of challenge of Indonesian Muslim in social and culture; (2) to analyze the political interests of film production company owner (meso) in his films; (3) to conduct textual analysis (micro) of two films which include Islamic values in the dialogues. Two films, Nagabonar Jadi 2 (Nagabonar Become 2) and Alangkah Lucunya Negeri Ini (How Funny This Country Is), were selected as samples for their contents that fearlessly criticize corrupt governance and promote integrity and good deeds. The three dimensions of critical discourse which was proposed by Norman Fairlough (1992) was used to evaluate the local film industry from the perspective of macro, meso, and micro. The macro-analysis found that Indonesian films act should be modified to keep up with modernized and recent trends in media and film industry. The meso analysis showed that competition between film companies are very though, however, film quality determines the popularity of the company in public. According to the company owner's agenda, Deddy Mizwar determines the quality of films produced, instead of quantity, as apriority. Thus, in post-reform era, the freedom of expression which enforced by the Act No. 9 of 1998, the company start producing Islamic films. Deddy Mizwar concerns for society are not only through the media but also political. He recently elected as the deputy governor of West Java province with the full support of an Islamic Party (Partai Keadilan Sejahtera). The textual studies have found similarities of the Islamic values in the content of the two films which are tawaqal (trust and reliance on God) and Taqwa, the pursuit of knowledge, respecting for the elderly, and belief in the Hereafter.
\end{abstract}

Keywords: film studies, Islamic values, macro analysis, meso analysis, miso analysis, Indonesia

Muhamad Fadhil Nurdin, Ph.D., Department of Sociology, Faculty of Social and Political Science, Universitas Padjajaran. Fitaha Aini, Master of Arts, Department of Communication, Faculty of Communication and Linguistic, Universitas Islam 45. Vina Effendi, Master Student, Department of Media Studies, Faculty of Arts and Social Sciences, University of Malaya. Mohamad Saleeh Bin Rahamad, Ph.D., Department of Media Studies, Faculty of Arts and Social Sciences, University of Malaya. 


\section{Introduction}

Recently, researchers have shown an increase of interest in media and religion. The noticeable tendency is that businesses see the media as a mean for opening the public sphere for a religious yet democratic discourse. Also, there are also ideas about religion that falls under the laws of economics, the law of supply and demand. Religion, which is presented in the media, eventually suffered a commoditization or becoming "merchandise" to sale. There is also a view that media are not only changing the appearance of religion but also affecting the perception of people about the teachings of religion.

The past twenty years have seen increasingly rapid advances in information technology which may promote public understanding of the specific religious teachings. However, there is increasing concern that media can also distort the religious teachings. Da'wah become commercial and superficial. Also, various media broadcasts often do not regard religious values. In fact, media can be an obsession, when people are addicted to it.

In modern society, the word "media" tends to refer to the means of public communication, either in published or electronic form (Mish, 1989, p. 737). By drawing on his concept, media in the sense of an intermediary is an important part of the religion. In 2006, Habermas specifically wrote about religion in the public sphere. He argues that scholars or audiences can use religious arguments and reasoning when discussing public issues, as well as audience shaving asecular view. Thus, complementary learning process could emerge. Subsequently, the public sphere has become important highlight in sociological and anthropological studies of religions, as shown in studies edited by Birgit Meyer and Annelies Moors (2006) as well as Nigel Biggar and Linda Hogan (2009). There is also a number of special study of Islam in public space (Eickelman \& Anderson, 2003), including about Islam in Indonesia (Mujiburrahman, 2007).

In terms of film, it is one form of media that instill changes in society by portraying reality. As described by Graeme Turner, film is a representation of reality in society (Sobur, 2006, p. 128). The depiction of reality by films makes them close to social life (Kolker, 1998, p. 13). The dynamics of film industry in Indonesia is supported by industrial capitalists which emphasize on profitability. Business motives have led to the birth of religious-themed movies as noted by Sri Rejeki in Kompas (2015). For instance, a successful film Ayat-Ayat Cinta (Verses of Love) in 2008 which managed to receive over 3.5 million viewers, encouraging similar films to emerge.

\section{The Trend of Islamic Films in Indonesia}

In the 1980s to the 1990s, Indonesian films were at rock bottom. Indonesian film industry was not capable of competing and keeping up with imported films. In addition, other constraints arose, such as financial issues, human resources within adequate expertise, as well as government policies that did not support the growth of film industry. Over the years, these problems had widened the gap between films, cinemas, and the audiences.

Indonesian film industry faced unresolved issues such as the lack of local films viewers. Representatives from the Indonesian Film Agency (BPI), Kemala Atmojo, reported that the root cause were mainly due to the poorly regulated film industry. The production house was not seriously producing local films.

Another factor affecting the quality of the film which resulted in diminishing interest from the audience was research. Media practitioners, particularly films, were less keen and focused in carrying out background study. Preliminary research must be conducted to ensure the accuracy of the history and background story which considered as crucial components that determine the quality of local films. For example, a film entitled 
Hafalan Shalat Delisa (Delisa's Memorized Prayers) which set in the coastal environment of Lhok Nga, Province of Aceh did not reveal the local culture as proven by the lack of the activities and local dialects used by the local community in the film's dialogue. Therefore, this film fails to convince the audience to believe that the story of Delisa was set in Aceh, not elsewhere.

In regards to film quality, compared to foreign films, Indonesian films were still not up to par in competing in story ideas. Such a cliché themes of love and horror film that comes with being indecently dressed actors were once dominated the local film world. Therefore, this had affected on the selection from audience with higher education background who always prefer foreign films that offer diversity in ideas.

As explained earlier, the filmmakers should have been able to explore alternative themes such as the history and culture of Indonesia. Many other themes can be correlated with the history and culture richness of Indonesia. The following films are considered good examples as being capable of presenting various topics in the Indonesian film landscape. A film entitled Sang Pencerah (The Enlightener) and Negeri 5 Menara (The Land of Five Towers) are films that represent not only the values of Islam but also the Javanese culture of life in those days.

The film Sang Pencerah (The Enlightener) and Sang Kiai (The Clerics) are Islamic-themed films that illustrate the life of Islamic scholars. Ainun Muhammad (2014) explored and investigated the role of Islam scholars in these films by using semiotic methods. The single most striking result from the data comparison was the great historical values. Moreover, the presence of two key figures, Ahmad Dahlan and KH Hasyim Ashari, as the triggers to the establishment of the first educational institution in order to implement a school model that embraces Islam theology and general science was also an interesting component. Both individuals was clerics who were described as someone who spear headed the revival of the Ummah to realize their fate as colonialized people. They announced that the oppressed must rise from adversity by seeking knowledge passionately. In the end, the two brave leaders issued a fatwa against the invaders. Clerics at that time are shown as modest individuals. They live as farmers who possess high willingness in learning.

In her textual semiotic analysis, Zakiyah (2008) proposed a Roland Barthes thinking to understand the moral message depicted in the film Ayat-Ayat Cinta (The Verses of Love). It was found that each scene in the film brings Islamic values. The film portrays the day-to-day life of Indonesian students in Egypt with features of Islamic morality in various symbols, such as mosques, the abaya, niqab, veil, and others. This research also found that there are denotation and connotation meaning, and it is compatible with the concept of Roland Barthes. Also, the actors used the verbal message in the film, which is a dialect of Arabic language used in everyday communication.

A broader perspective has been adopted by Wijayati (2012) who argues that appropriate and effective use of media has resulted in a more effective understanding of Islamic teachings to the public. The result shows that the depiction of the moral beliefs in the film Ketika Cinta Berstasbih (When Love Glorifies God) to the creation of individuals who always draw closer to God. The characters in the film are portrayed with admirable characters such as obedience, piety, patience, well-behave, keen learner, determined, verbal modesty, respect for teachers, honor and obey parents, avoiding arrogance and envy. Some of the above traits were described in a form of a story set in Islamic educational institutions, the University of Al-Azhar in Cairo. Morals conveyed in this film is the mahmudah deeds because it is by the teachings of God, both from the worship and Islamic point of views. This film also provides a message to develop karimah characters in an attempt to erode the moral decline in the society. 
The rapid development of Indonesian film industry in recent years has proven that there has been an enhancement in the film industry that not only sells entertainment but also convey moral values that can be followed. For example, documentary films called Naga Bonar, Naga Bonar Jadi 2, and Laskar Pelangi (Rainbow Troops) which help movie fans to understand the phenomenon that occurred in Indonesia without diminishing hopes and ideals in facing the future. Similarly, the film, entitled Kiamat Sudah Dekat (Apocalypse is Nigh) which feature Deddy Mizwar as the lead actor to be one of the earliest films that introduce religious values. This film has inspired national film industry for being the originator for the birth of the Islamic-nuanced films.

Behind the awards received by Deddy Mizwar and his colleagues, there is vast opportunities to be studied. In particular, this study aimed to address the following Research Questions: How do the social and cultural conditions of Muslims influenced the development of film in Indonesia? What role did Deddy Mizwar play as an intelligent Muslim to strengthen the Islamic values in the local film industry? What Islamic values conveyed in his works?

\section{Methodology}

Critical discourse analysis is the process of elaboration of a text (social reality) from an individual or dominant group that have a specific purpose. This statement suggests that in a context, the importance of its essence must be realized (Meyer \& Wodak, 2009). The importance of this principle will affect the media process and media content.

It was decided that the most suitable method to adopt for this investigation is to apply a discourse analysis approach by Norman Fairclough (1992b, 1995a, 1998, 2000), known as the three-dimensional discourse analysis. A three-dimensional discourse analysis involves three stages of analysis: (1) textual analysis (micro), which is an elaboration of the text; (2) analysis of discourse or discourse practice (meso), the understanding of the relationship between text and discourse production process; (3) the socio-cultural analysis (macro), the explanation of the relationship between the discourse process and social process (Fairclough, 1992a, p. 73; 1995a, p. 59; Idris, 2006, p. 75).

The first dimension which is the micro dimension in Fairclough's critical discourse analysis frame work is the textual analysis dimension. This analysis includes traditional forms of linguistic analyses - analysis of vocabulary and semantics, grammatical sentences, sounds (phonology) and writing system. Fairclough stated that the process described above as "linguistic analysis", although it uses the term in the expanded view (Fairclough, 1995a, p. 57; 2000, p. 311). The second dimension is discourse practice. In this dimensional analysis, interpretation of discourse process is carried out which includes aspects of generation, distribution, and use of the text. Some of the components have a more institutional character, while others are the processes of use and dissemination of discourse. Lastly, the third dimension of the analysis as the socio-cultural activities of the media is a macro-level analysis which is based on the existing social context outside media, including external conditions that affect media production process in media discourse. The newsroom is not a sterile empty space but is also determined by factors outside the media itself.

Fairclough (1992) stated that social activities have various purposes such as economics, political, social, cultural, ideological, and so on. Discourse is a bigger picture of all of the said issues. Thus, dimensional analysis of social activities refers to the problems associated with various orientations related to the above, such as values, beliefs, ideology, philosophy, culture, and others contained in the discourse (Idris, 2006). 
Figure 1 outlined the Norman Fairclough's three-dimensional discourse analysis, capable of holistically depicting the Indonesian film industry.

Fairclough (1992) introduced the three-dimensional analysis of media discourse. In the context of macro-analysis, the film industry in Indonesia is reviewed based on the movie trend while socio-cultural analysis seen in the framework of problems and intellectual challenges of Muslims in Indonesia. The two main components are linked and studied in depth. The following stage of the study is meso analysis. Film production house and the owner's political agenda, Deddy Mizwar, were assessed in depth. Following this, his career as an actor, director and film producer will be equally highlighted. This study does not only focus on his contributions to the film industry but also to political realm.

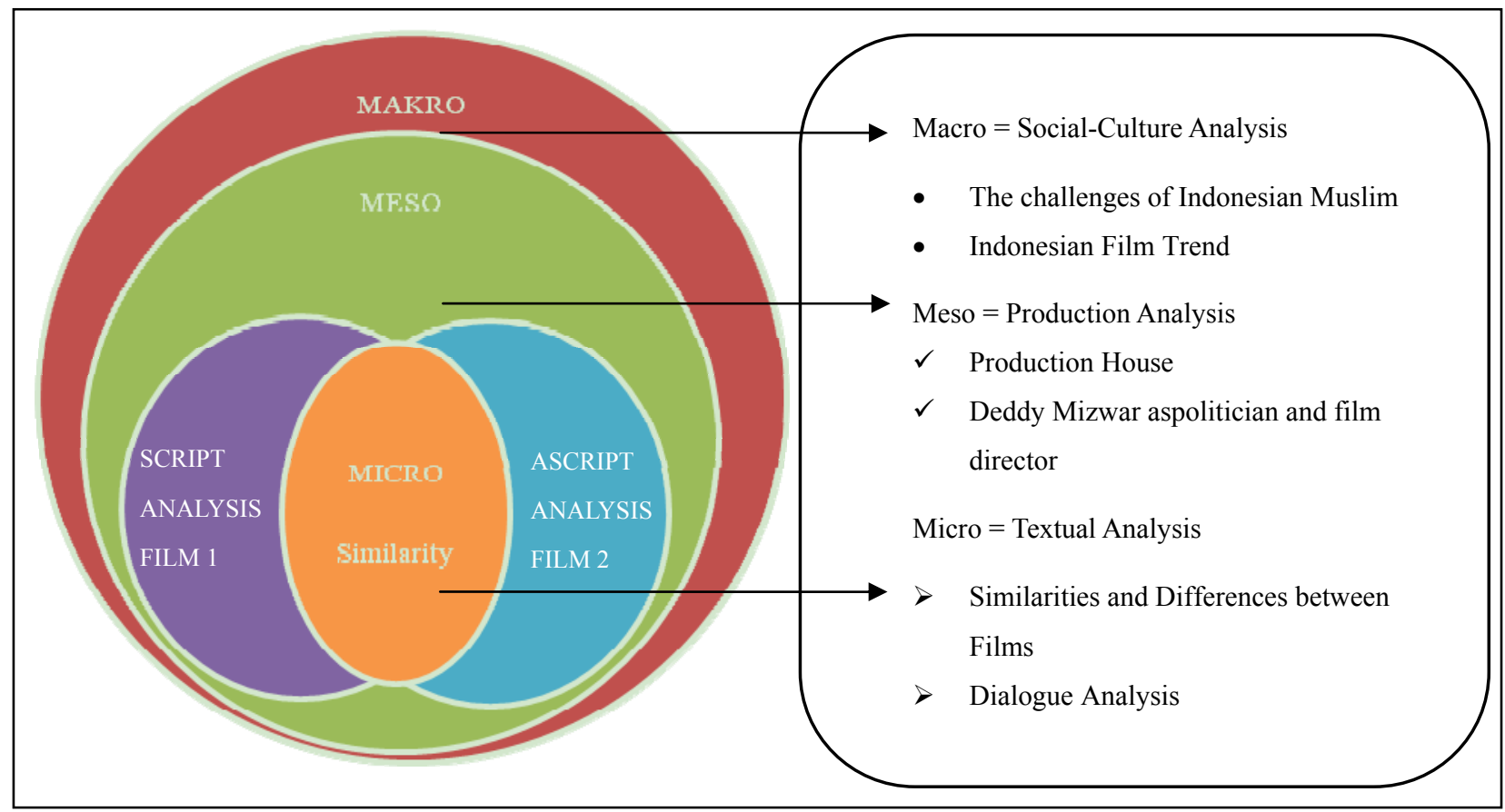

Figure 1. Conceptual framework. Modified from: Three-dimensional discourse analysis (Fairclough, 1992).

With the sheer number of scholars, critics or journalists paying attention to the development of Indonesian films, it is very reasonable for the authors to investigate the two films entitled Nagabonar Jadi Dua (Nagabonar Becomes 2) and Alangkah Lucunya Negeri Ini (How Funny This Country Is). Those films, under the direction of Deddy Mizwar, were selected for this study because messages conveyed the Islamic values in the current media production. The last stage is the micro analysis which is a textual study of two selected films.

\section{Results}

\section{Macro Analysis: Indonesian Film Industry in the Context of Social and Culture}

The main problem for Muslims in Indonesia nowadays is lagging behind for most aspects of life particularly in education, science, technology and economy (Maarif, 2016). Although Muslims are the majority, they are considered weak in all realms. This has resulted in their presence as a heavy historical burden. Non-Muslims largely dominate economic institutions. In the realm of education, however, there is progress, but not evenly spread out. In addition, Muslims perform a variety of religious traditions, Hindu influence has not disappeared altogether. 
Technological advancements from time to time has resulted in the progress of Indonesian film industry. However, Indonesian filming industry is damaged by a tiny fraction of individuals who are only looking for profit. This opportunity is used by certain film production house to produce shallow horror films with subtle obscene elements. This is certainly very disturbing because the film is not benefited for promoting education and dissemination of valuable messages. Films are used to gain anadvantage by waiving the modesty of Indonesian cultural identity (Haryadi, 2013). Explicit or obscene film genre are produced to attract cinema audience. This is a hopeless situation, which makes local films increasingly marginalized due to lack of quality.

Based on the above factors, the macro analysis was also associated with the existing acts and regulations that must be adhered to ensure the quality of Indonesian films. The institutional board recognized by the Indonesian government such as the Film Agency for Indonesia (BPI) shall support and protect the film industry in Indonesia along with the influx of foreign films. Film Censorship Board (LSF) has not been able to play its role optimally as not being fair in granting approvals. Even so, competition between film producers still continues to be driven by young intellectuals.

By the turn of 21 st century, the number of young Muslim intellectuals are increasingly spreading to produce works that are more contemplative. However, there was virtually no significant development observed from Muslims scholars during the last decade (Latif, 2005). This is because democratic freedoms are celebrated with mediocracy which tends to be anti-intellectualism. Also, the majority of Muslim intellectuals are more interested into the realm of practical politics by joining political parties which did not publicly represent the interests of the nation as a whole. This phenomenon is known as "politics for a living" (Maarif, 2016).

However, there are a small number of Muslim intellectuals who fight and survive in the current epoch. They have works adored by the public. History proves the existence of their quality of works. They are bold to voice their opinions and what they stand up for in the interest of public awareness. Deddy Mizwar is one of Muslim intellectual who played that role in the Indonesian film industry.

\section{Meso Analysis: Deddy Mizwar in Indonesian Films}

Deddy Mizwar's career journey has given a great contribution to Indonesian film industry. The Intellectual, vision, and mission of Deddy Mizwar in creating a work of art is not just for profit, but also as a platform to call for goodness and truth. As senior actor and film director, he knows how to strengthening the Islamic values in this current modernization age.

His efforts were not considered unchallenging since, at that time, Indonesia was undergoing political reform from an authoritarian regime to a liberal regime. Freedom of speech had resulted in rapid increase of media products such as books, music, newspapers and movies but simultaneously, there was a decline in the quality of mass media due to a loss in the sense of identity and visions. Therefore, Deddy Mizwar's creations were like a "wake-up call" when the audience were starting to enjoy liberal regime.

His philosophy in many films shows the ideology as reflected in his ways of thinking and acting. His films have always ventured out of the genre that dominated at that time, so he is renowned for bringing fresh and smart ideas. Some of the films released are comedy because this genre is adored and understood by audience of any age groups. However, the humor contained in many of his films are full of criticism towards the government.

The production company PT Demi Gisela Citra Sinema was indeed not been able to compete with the other main film production houses, judging from the quantity of films that have been produced. However, he has a fundamental principle to produce quality films which contain positive values. He is widely known as a 
figure of integrity and idealism in his career. After being an actor and film producer, he was inaugurated as president on the board of the film under the government of Indonesia, the National Film Advisory Board (BP2N) 2006-2009. By becoming president of this organization, he made a major contribution in improving film quality, supporting filmmakers and actors and overcoming the issues in the film industry.

In 2009, he registered to be a candidate for President of Indonesia with Brigadier General Saurip Kadis as his deputy and were supported by some small parties in Indonesia. However, his effort stalled because the requirements to run for the presidential candidates were not adequate with the regulations set by the Constitutional Court of Indonesia. Based on several media, he was interested in serving the public as an obligation of a Muslim. After the failure of the nomination of the President, finally he entrusted to the Vice Governor of West Java Indonesia accompany his friend, Ahmad Heryawan. Currently, he is a leader due to democratic process which entrusts a new role for him.

\section{Micro Analysis in the Films Nagabonar Jadi 2 and Alangkah Lucunya Negeri Ini as Platforms to Disseminate Islamic Values}

These films, Nagabonar Jadi 2 (Nagabonar become 2) and Alangkah Lucunya Negeri Ini (How Funny This Country IS), provide important messages to the audience. The results of the study showed that the two films spread a message of moral calling across. This textual study as a result of analysis of the micro structure indicates that Indonesian culture is still upholding religion as a guidance in life. Deddy Mizwar always disseminate Islamic message in universal forms that can be accepted by all religions. Enlightenment through popular media is transmitted by a creative approach. At first, viewers were taken in the life story of a city full of humorous scenes, but positive message implied is repeated several times in different scenes for the audience to understand the emphasis on Islamic values to be conveyed.

Textual Analysis of Nagabonar Jadi Dua. a. Message of the pursuit of knowledge:

1. Nagabonar: Not in vain I sent you abroad.

Bonaga: Father want me and my friends to be successful, right?

Nagabonar: Yes. If it was not you who are young, who else?

(Dialogue between Nagabonar and Bonaga. Nagabonar proud to have a young son but had success with work and life). $22.56-23.06$

The dialogue illustrates the situation when Nagabonar comes and sees a mansion owned by his son. He is proud of his son's career. Bonaga is successful after he completed his studies abroad. Nagabonar is a national hero who fought against the invaders. Since his mother and wife passed away, he raised his son alone.

Regarding education, the problems faced by society today is an inequality of access to education. First-class education can only be enjoyed by the wealthy. Although government provides schools without charge, the competition is intense. Also, other problems also arise from some people who come from the lower middle class. They still believe that schooling does not benefit them as the outcome may not be produced in a short period.

b. Message of respecting the parents/elderly.

1. Bonaga: I can't sleep, dad.

Nagabonar: When you were little, if I wasn't stroking your head, you couldn't sleep.

Bonaga: But now I'm an adult. I am graduated from abroad.

Nagabonar: Just this once, Bonaga. Okay?

Bonaga: Up to you. (Dialogue between Nagabonar and Bonaga. Nagabonar is stroking his son's head and Bonaga fell asleep). $15.27-15.51$ 
2. My father is worth more than this. (Bonaga says that he loves his father more than the projects from Japan's investor. Although the project is predicted to offer a great profit, he prefers to cancel it). 1.51.10 - 1.51.17

This story shows the values of Indonesian that emphasizes respecting for others. The love of a father for his child is presented in dialogue 1. This Islamic value shall be nurtured in the family as the smallest social institutions. The habits of the caring family member are described in several scenes. For instance, Bonaga always kissed his hand before he left. This habit is one of the Malay customs. He retained this habit even though he studied overseas and is living in a big city.

The hardest decision he ever made is terminating the contract with Japanese company as evidence of respect to his father (dialogue 2). Bonaga must go through a struggle of idealism. A profitable project, as well as his father's wishes to keep ancestral lands, poses a dilemma situation. Nagabonar shows a strong statement of his life not to accept the offer of the foreign investor because development cannot only be measured by the number of luxury buildings but also the intention of preserving historical and cultural places.

c. Message of Tawaqal and Taqwa.

(1) OK. Now I want to pray. Later when he wakes up, tell him to wait. Usually, people like him always forgets to pay the fare. Astagfirullahalazim. It is a sin. I should pray. (This dialogue takes place between Baja driver 2 with friends. He complained because too tired looking for Nagabonar's house) $29.38-29.48$

(2) Your mother and grandmother are also Muslim. But, I'd never seen them after they prayed, danced like that. (Nagabonar tells Bonaga while they are watching at Zaki and his friends who are dancing in a nightclub). 1.10.31 - 1.10.37

(3) Eh, you select a carpet which is suitable for Omar's mosque. So that young person like you wants to enter a house of worship. (Nagabonar asks Bonaga and his colleagues to contribute to the mosque carpet). 1.53.24-1.53.31

The films attempt to show that Muslim shall come always to taqwa. Dialogue 1 portrays although motorbike driver is tired of working from morning to night, he still prays. In contrast, the above dialogue also illustrates the religious observance of Muslim in Indonesia. Implementation of worship is just a routine in life. Religion does not absorb the words and deeds of followers. Although the he shows his eagerness in shalat he has prejudice to Nagabonar which is not justified by Islam. He thinks that Nagabonar will not pay the fees.

The same scenes are also depicted in dialogue 2 and 3. Zaki is Bonaga's close friend. He is a young Muslim from Arabian family. He is shown as a devout follower but loves drinking beer and having fun at anightclub. In another scene, he also feels proud of his ability to reduce the tax which must be paid to the government. This situation creates confusion to Nagabonar as a conservative villager. Although he is not a devout follower, he thinks the habits of figure Zaki, his wife, and his mother are contradictory. These two women attended a very observant religious life. Words and actions never conflict with the rules of Islam.

Nowadays, the development is marked by a growth of information technology which influence people's living habits. Older and younger generations have different mindset and behavior. Cultural and religious values that are understood and carried out has undergone a shift. Most young people who live in the city meaning of religion as a ritual or activity performed continuously without understanding the main message of any religious worship. Prayer should be a protection against wrongful act. The film implies worship has no effect on behavior of Zaki and Motorbike driver 2. The last dialogue illustrates Nagabonar asked his son to choose carpet for the mosque. This dialogue also implies agreat desire of the older generation, so that young people like his son is excited about going to the mosque for praying.

However, ibadah must be based on the five pillars to develop a good and moral existence of Muslim: Declaration of faith (shahadah), Prayers (Salat), Zakat (self and property purification), Fasting (Sawm), and 
Pilgrimage to Makkah (Hajj) (Abdalati, 1986; Haneef, 1999). Furthermore, in an Islamic context, refers to the Quranic commandment which mentioned in the praying text as follow: "O.Allah blessed us with kindness (Hashanah), both in the world and in the hereafter". Simply, the term of Hashanah can be defined as: kindness, welfare, and happiness (Nurdin, 2015b).

d. Message of believing the hereafter.

1. It is impossible without learning. You have to teach me how to read Al-Qur'an, Umar. I am already old. If I die, then how I met my mother in the after life. If my mom knew that I could not do it, I would get yelled at. If she gets angry, she can start from early morning and stop at late evening. Her mouth likes a rifle, itching all my body. If I go to heaven, all will be okay. However, if I go to hell, it is hot and itchy. Please teach me to read the Al-Qurán. (Dialogue between Nagabonar and Umar about the importance of the Koran to the provision in the hereafter). 1.24.33 - 1.24.58

The main topic in the dialogue 2 is a call to do good. Nagabonar's request to learn Al-Qur'an shows that it is not too late to learn. Despite his age, he is still eager to learn it although he has to study it with children.

e. Message of Respect to Women.

1. Women are still women, still wants to "ditinggikanseranting, dilebihkansebenang" (Malay Proverb; respected). (Nagabonar asks Bonaga to send Monita to her house as a way to respect and protect a woman) $1.18 .50-1.18 .57$

2. Your mother is more than enough as a wife. Her love was so huge and wide until I was not able to contain it. So, I don't have to find another woman. Secondly, your grandmother is more than enough as a mother. Her love is unlimited. She told me to learn in school, I ran. She asked me to study Al-Qur'an, I pilfer. However, she still loved me. So I'm not looking for another mother. Your grandmother is the one forever. (Dialogue between Nagabonar and Bonaga about the special position of women in the eyes of Islam and the Malays). 1.19.19-1.19.51

The dialogue reflects Indonesian cultural identity of appreciating a woman. Based on the history, women occupy the honor position. Emancipation of women has started since the era of Kartini. Kartini fought for gender equality so that women have equal rights in education and careers. This matter is shown by the acceptance of the people of Indonesia to the fifth President of Megawati Soekarno Putri. Leadership transition from Abdurahman Wahid (president-4) to her did not cause conflict in society.

Monita is portrayed as a pretty, intelligent and independent woman. However, she still holds modesty and courtesy by keep waiting for a declaration of love from Bonaga though she has admired him for a long time. This film attempt at showing that women's nature is to be respected and protected.

Malay culture which upholds a mother and wife accordance with Islamic values. This reason proves that Malays and Islam have a strong bond. Dialogue 2 illustrates the loyalty of Nagabonar as a husband whose wife had died. As proof of his loyalty, he nurtures Bonaga alone and decides not to marry again. In addition, his respect for his mother is always shown in a scene when he remembers her sacrifice. She always encourages him to learn Islam. This case in accorandce with Islamic values that put the mother as the first madrasa for his son.

Textual Analysis in Alangkah Lucunya Negeri Ini. a. Message of seeking beneficial knowledge.

1. Educated people can always solve the problem. (Dialogue Makbul with Sarbini). 6.21-6.26.

2. Japan is known as a developed country because of the education level of its citizens is high (Makbul keep stressing education is important). $7.30-7.32$

3. Education is important if there is a connection. If there is no network, it's useless (Dialogue Sarbini with Makbul). $14.14-14.19$

4. I don't mind if my income is reduced. The most important thing for me is the future of children. (Dialogue Jarot to Muluk full of hope for his students). $40.55-41.07$ 
5. People who are not educated can collect money 5 million a year. An educated person could collect 5 million Rupiah in a month and even week. (Samsul provides an overview to pick-pockets on the benefits of learning). $43.58-44.0$

6. Now you can try to think. Thinking it is not easy. To be able to think properly, based on my experience, it took 17 years, from elementary school until college. (Kampret were asked to think by Muluk then he drop). $26.07-26.35$

Deddy Mizwar as the director of the film wanted to show and emphasize education as an essential matter. Education is useful for troubleshooting (dialogue 1), thinking correctly (dialogue 6), having a prosperous life (dialogue 5), having a bright future (dialogue 4) and developing countries (dialogue 2). It can be obtained not only from the school or any official institutions but may also be conducted non-formally (dialogue 4).

The films also rely on the idea of the education problem. It begins with the image of society's perception that education is not important to the betterment of life. Communities dominated by the lower classes think that success can be obtained without attending school. Dialogue 3 shows Makbul's perception about networks is the key factor in determining a person's success. In another scene, he also suggested Muluk to be a t-shirt merchant rather than working as employees of the company.

This view is considered capable of influencing the social relations by creating the gap between the educated and the uneducated. Muluk and his friends initiative to build non-formal education institutions to guide the pickpockets, but they did not get full support from local community. The conflict between idealism and reality that is reflected from the social system, the legal and political lead this effort stalled in the middle of the road. At the end of the story, pickpockets change their path to be a street vendor, selling food on the street. For some people, these changes should be supported and encouraged. However, the legal system considers sellers who were selling in street is a crime because it can lead to accidents.

These values lead to internal interactions to form a new identity. External factors result in identity and values conflicts that influence their paradigm. At the end of the story, the values from external parties do not give a significance impact on the pickpocket group since they refuse to keep learning and became merchants. However, Komets and his friends agree to receive a new value as positive things. In other word, these ideas have changed their knowledge, attitudes and behaviors indirectly.

b. Message of respecting the parents/elderly.

1. The prize is a Umrah package, Dad. If I win, you take the prize. (Rahma is showing affection to her father. As unemployed, she is still dependent on their parents. Every day she participates the game show on television). 11.39-11.43

2. Muluk: It is stolen money. Rahma: Bang Samsul, could you give stolen money to your mother? (Dialogue between Muluk, Rahma, and Samsul who finally decided to stop accepting stolen money from pickpockets). 1.23.29 - 1.23.33

The dialogue reflects the desire to reward the contributions and sacrifices of her parents. Islamic values inherent in each is influencing their understanding of halal and haram. The love of a child is also reflected in the film. Dialogue 1 and 2 portray the spirit of a child who wants to make their parent happy even if it is not appropriate.

c. Message of Tawakal and Taqwa.

1. You should often ask for forgiveness to God, for His guiandce. So that you may be given the right path. (Rahmat advised Muluk to think positively when he wasn't getting a proper job). $9.41-9.48$

2. Do not forget to read Basmillah (Seller tells Jarot always to recite Bismillah before drinking). $18.53-18.55$ and $38.58-39.01$

The conversation on the moral values above presents the idea of trust (dialogue 1) and obedience to God (dialogue 2). Dialogue 1 means that human should rely on and trust in God after every effort has been conducted. 
Deddy Mizwar, who think that film as a platform to disseminate the message of kindness, is attempting to convey audience with the universal moral values. Therefore, most of his films are well-received by people.

In this film, there are repeated similar dialogues (2) which are delivered in different scenes. This sentence pronounced by the owner of a coffee shop to Jarot, the pickpocket leader. The first scene, when Jarot and all children pickpockets are enjoying dinner. Having served coffee, coffee shop owner delivers these words. The second scene, when Jarot gives money to other gangsters as a fee of protecting them and the coffee shop owner says the same thing.

This study finds that the sentence is a satire on Jarot, who makes money by illegal means. As a seller, he has limited interaction with the buyer. If he is too bold to advise Jarot, it would be dangerous for his safety. However, he believes that every Muslim has a duty to speak the truth and advised the kindness and patience. The word "Bismillah" is a sentence that is always read before starting any activity so that all the works are accepted by God. Indirectly, coffee shop owners also hope that Jarot and immediately pickpockets repent and return to the righteous path.

d. Message of believing the hereafter.

1. Everyone must die. You only have two choices, hell or heaven? Hell is not nice, while heaven is nice. Therefore, I introduce you, Ustazah Pipit to teach religion subject, so you can go the Heaven. (Muluk talks to the pick-pockets about the importance of religious learning for the provision in the hereafter) $55.39-56.02$

The film also relies on the idea of the condition of majority Muslims in Indonesia who are full of religious ritual but an empty soul. Dialogue (3) illustrates the role played by Pipit as a teacher of the Islamic religion. When she teaches religion subject, she introduces the basic concepts such as letters hijaiyah, a short prayer, ablution, and prayer so that the pickpockets do not feel bored during the lesson. Also, the dialogue above also illustrates that the Muslim must believe in the Resurrection and the Hereafter because it is part of the pillars of faith. The quality of a person's religion will determine the position in the afterlife.

f. Message of tolerance.

1. Religion shall be taught here is the religion of Islam. For students who are not Muslim, I'll find a replacement teacher. (At the time, most of the pickpockets do not know their religion. Even though Pipit was aware that searching for a substitute teacher would take time and energy, but she still offered help to find another religious teacher, as a part of tolerance towards people of different religions). $56.55-57.05$

Dialogue (4) describes the interest of respecting different believers. The last sentence in this dialogue shows Pipit desire to find a teacher for non-Muslims. In Indonesia, Islam is not the official religion of the state. There are six recognized religions, but the majority of the population are followers of Islam. Therefore, the tolerance is a fundamental matter in cultivating harmony among people of different faiths. Under the constitution of Indonesia (1945) Article 29, paragraph 2: "The State guarantees the freedom of each citizen to profess his religion and to worship according to their religion or belief". This chapter is defined as the principle of liberty to embrace and practice the religion for all citizen. The state is obliged to protect and act equitably. Maarif (2016) argues that inter faith relations in Indonesia be relatively safe. If there is interference, the main reason is not that of religious differences, but the perspective of a minority who forced his religion as the ultimate truth (Ibid.).

e. Message of Hygiene and Cleanliness.

1. Purity is half of iman (faith). We cannot wait for the arrival of the rainy season. Thus, you have to shower. (Dialogue Pipit teaches hygiene is important). $58.12-58.27$ 
Cleanliness is another Islamic value which is presented in this film. Islam loves beauty and cleanliness. Health, cleanliness, and hygiene occupy a significant part of Islam's attention. A Muslim is required to be clean when performing daily Prayers, which includes properly cleansing oneself after using the toilet and practicing ablution. Moreover, the enormous encouragement for cleaning teeth as shown in the hadiths reveals to which extent Islam arrange even for the details of personal health and cleanness. Therefore, Pipit conveys the hadith of cleanliness is part and parcel of faith.

\section{Discussion}

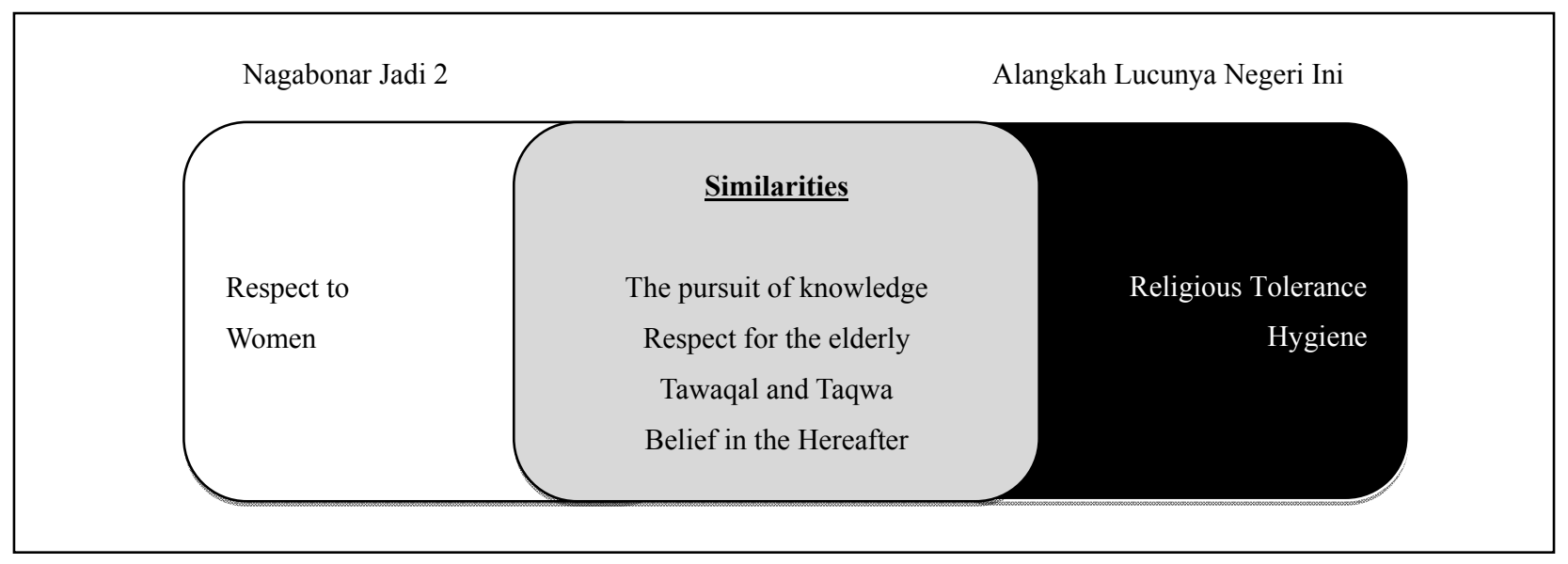

Figure 2. The similarity of the message.

Figure 2 presents the result obtained from the similarities and differences in the two films. Data from this figure can be compared with the data in micro analysis (textual) in the paper. From the data in Figure 2, it is apparent that similarities of Islamic values in two films are the importance of the pursuit of knowledge, respect for the elderly, Tawaqal, and Taqwa, and believe in the hereafter. There are also differences that appear in these films. Nagabonar Jadi 2 which the main theme is the love of the homeland (nationalism), has content about the position of women in Islam. While the main theme of Alangkah Lucunya Negeri Iniis crime, robbery and corruption. It also disseminates Islamic message of religious tolerance and hygiene.

This finding has proven that there is a rise of Islamic values in the Indonesian film industry. It is in agreement with Wijayati (2012) result which showed the Islamic values that are contained in these two films are consistent with Islamic values in the film of Ayat-Ayat Cinta. For instance, the pursuit of knowledge, Tawakal and Taqwa, and respecting the elderly are the Islamic values that appear in the Indonesian films.

The films depict people can find moral and spiritual values that are rich in human behaviors, but also are able to find human lust for wealth, fame, and power that camouflaged by religion. Indirectly, these two films illustrate the impact of religion as a ritual without a soul is a moral decline. Characters portrayed in this film are citizens who have a basic religious knowledge of right and wrong, but they often commit sinful acts.

This result may be explained by the fact that religion as a fact certainly not always in line with religion as a normative reference (Mujiburrahman, 2015). Normative religion forbids corruption, but followers of the religion could be corrupt. Religion as a social and historical reality continues to experience dynamic, sustainable changes, likely to be complex and full of nuances, which are often difficult to judge in black and white, right and wrong. Religion as a social and historical reality, aware of the strengths and weaknesses of human beings who believe in themselves. 


\section{Conclusion}

Currently, a struggle of power among the elites who use God's name is damaging state institutions. Ongoing conflicts and corruption that occurred in clerical institutions, the parliament, and the government led to the slow development process. Also, the cultural change due to the development of communication technologies diminish the moral and ethical values of society.

In the end, it can be concluded that social, culture and media development (macro) and Deddy Mizwar ideas (meso) as an influential figure in these films, Nagabonar Jadi 2 and Alangkah Lucunya Negeri Ini, is reflected in the similarities and differences of messages about Islamic values (micro). Methods of analysis of three-dimensional from Fairclough has proven that holistic analysis can shed some light on the cultural identity associated with Islamic value which is believed and practiced by the community can be clearly defined.

Regarding of textual analysis, the present study confirms the previous finding and contributes additional evidence that suggests other Islamic values in film content such as respecting women, believe in hereafter, Religious tolerance and hygiene. Besides, further research needs to examine more closely the link between film and religion. More information on film industry would help the reader to establish a greater degree of accuracy on this matter. By combining textual analysis and interviewing National Film Advisory Board officials and filmmakers could provide holistic perspectives.

The findings of this study have a number important implications for future practice. Moral content in the film which educating, empowering and enlighten should be taken into account when formulating policy for the film industry. There are some important changes need to be made to supporting local film industry such as implementing professional bureaucracy, encouraging fair competition and promoting local film actively in the international film festival. In addition, it shall be utilized by the community, filmmakers, and government so that they can play significant roles in promoting the national film.

\section{References}

Abdalati, H. (1986). Islam in focus. Jeddah, Saudi Arabia: WAMY.

Andiel, S. A., Jhony, S., \& Max, R. (2015). Analisis Semiotika Film “Alangkah Lucunya Negeri Ini”. Jurnal Acta Diurna, 4, 1-8.

Eickelman, D. F., \& Anderson, J. (2003). New media in the Muslim World: The emerging public sphere. Bloomington: Indiana University Press.

Fairclough, N. (1992a). Discourse and social change. Cambridge: Polity Press.

Fairclough, N. (1992b). Discourse and text: Linguistic and intertextual analysis. Cambridge: Polity Press.

Fairclough, N. (1995a). Media discourse. London: Edward Arnold.

Fairclough, N. (1995b). Critical discourse analysis: The critical study of language. London: Longman.

Fairclough, N. (1998). Political discourse in the media: An analytical framework. In A. Bell, \& P. Garret (Eds.), Approaches to media (pp. 142-162). Massachusetts: Blackwell Publisher Inc.

Fairclough, N. (2000). Critical analysis of media discourse. In P. Marris, \& S. Thornham (Eds.), Media studies a reader (pp. 308-328). Washington: New York University Press.

Haneef, S. (1999). What everyone should know about Islam and Muslims. Delhi: Adam Publishers.

Hariyadi. (2013). Islamic Films and Identity: The Case of Indonesian Muslim Youths. Proceeding from The $5^{\text {th }}$ International Conference of Indonesian Studies: Ethnicity and Globalization, Yogyakarta.

Idris, A. (2006). Bahasa dan Kepemimpinan Analisis Wacana Mahathir Mohammad. Bangi: Penerbit Universiti Kebangsaan Malaysia.

Kolker, R. (1998). Film, form and culture. New York: McGraw-Hill Humanities/Social Sciences/Languages Company Inc.

Latif, Y. (2005). Muslim Intelegensia dan Kuasa: Genealogi Intelegensia Muslim Abad Ke-20 (1st ed.). Bandung: Mizan.

Maarif, A. S. (2016). Indonesian religious and intellectual tradition: contemporary challenges. Lecture. 
Meyer, M., \& Wodak, R. (2009). Critical discourse analysis: History, agenda, theory and methodology. In M. Meyer, \& R.

Wodak (Eds.), Methods for critical discourse analysis (introducing qualitative methods series) (2nd ed.). Los Angeles: Sage Publications Ltd, United Kingdom.

Mish, F. C. (1989). Webster's ninth new collegiate dictionary. Ontario: Thomas Allen \& Sons.

Moein, T. A., \& Mizwar, D. (2007). Nagabonar Jadi 2 [Motion Picture]. Indonesia: Demi Gisela Citra Sinema.

Mujiburrahman. (2007). Indonesian Muslims in the public sphere: A review of several studies. Journal of Indonesian Islam, 1(2), 356-378.

Mujiburrahman. (2015). Agama, Media dan Imajinasi: Pandangan Sufisme dan Ilmu Sosial Kontemporer. Banjarmasi: Antasari Press

Nurdin, M. F. (2015a). Sociology and welfare development. Yogyakarta: Penerbit Samudra Biru.

Nurdin, M. F. (2015b). Addressing poverty through the lens of social development model: An application for spirituality. Proceedings from The 2nd International Social Work Conference. Penang: Universiti Sains Malaysia.

Onik, Z. (2008). Pesan moral Islami in film Ayat-ayat Cinta: Kajian Analisis Semiotik model Roland Barthes and Model Wacana Van Dijk (Unpublished Master's Thesis). Institut Agama Islam Negeri Sunan Ampel, Surabaya, Indonesia.

Sobur, A. (2006). Semiotika Komunikasi. Bandung: PT Remaja Rosdakarya.

Wijayati, A. B. (2012). Kajian Nilai Pendidikan Aqidah Akhlak dalam Film Ketika Cinta Bertasbih (Unpublished Master's Thesis). Institut Agama Islam Negeri, Walisongo, Indonesia.

Zain, Z., \& Mizwar, D. (2010). Alangkah Lucunya (negeri ini) [Motion Picture]. Indonesia: Demi Gisela Citra Sinema. 